\title{
Remark on Citations
}

Page references to works by Quentin Meillassoux appear in parentheses in the text itself, in the form of an abbreviation followed by a page number. For example, (AF 92) means page 92 of After Finitude. A key to the abbreviations of Meillassoux's works appears below, and full bibliographical information on these writings can be found in the list of Works Cited at the end of this book. References to works by all other authors appear as endnotes following each chapter.

Citations from Ray Brassier's translation of After Finitude appear courtesy of Continuum Publishing. Translated excerpts from the unpublished French manuscript of L'Inexistence divine (The Divine Inexistence) and the whole of the 'Interview with Quentin Meillassoux' appear courtesy of Meillassoux himself; both are published in the present work alone.

\author{
$\mathrm{AF}=$ After Finitude \\ $\mathrm{BL}=$ Berlin Lecture ('Iteration, Reiteration, Repetition') \\ $\mathrm{BM}=$ 'Badiou and Mallarmé' \\ $\mathrm{CL}=$ 'The Contingency of the Laws of Nature' \\ $\mathrm{DI}=$ The Divine Inexistence \\ DU = 'Decision and Undecidability of the Event in Being and \\ Event I and II' \\ $\mathrm{HE}=$ 'History and Event in Alain Badiou' \\ $\mathrm{IW}=$ 'The Immanence of the World Beyond' \\ MS = 'Metaphysics, Speculation, Correlation' \\ NS = The Number and the Siren \\ $\mathrm{PV}=$ 'Potentiality and Virtuality' \\ $\mathrm{QM}=$ 'Interview with Quentin Meillassoux' \\ $\mathrm{SC}=$ 'Subtraction and Contraction' \\ $\mathrm{SD}=$ 'Spectral Dilemma' \\ $\mathrm{SR}=$ 'Speculative Realism'

